Teologia i Moralność, volumen 14(2019), numer 2(26)

doi: 110.14746/TIM.2019.26.2.8

ORCID: 0000-0002-6186-4422

\author{
JÓZEF MŁYŃSKI \\ Uniwersytet Kardynała Stefana Wyszyńskiego w Warszawie \\ Wydział Studiów nad Rodziną
}

\title{
Społeczno-wychowawcza rola seniorów (dziadków) w rodzinie
}

Funkcja wychowawczo-socjalizacyjna jest jedną z podstawowych spośród tych, jakie pełni rodzina w społeczeństwie. Pierwszymi wychowawcami wpływającymi na proces rozwoju dziecka oraz kształtowanie jego świata wartości są rodzice. Oni też odgrywają pierwszorzędne role w zakresie zapewnienia: opieki, wsparcia, bezpieczeństwa, przynależności i miłości, gwarantując każdemu społeczeństwu oraz cywilizacji ciągłość biologiczną i kulturową. Ważną funkcję w życiu każdego dziecka, chociaż drugorzędną, pełnią również dziadkowie będący dla wnuków „wychowawczym ogniwem pokoleń”. Szczególnie w społeczeństwach postindustrialnych ewoluujących w kierunku: konsumpcjonizmu, społecznego zaangażowania w dziedzinie nauki, permanentnego czasu pracy, migracji zarobkowej, które w centrum systemu aksjologicznego umieściły aktywność instrumentalną, instytucja dziadków jawi się jako istotna przestrzeń funkcji wychowawczo-socjalizacyjnej.

Rodzina od pierwszych form jej powstania i ustrukturalizowania społecznego odgrywała i odgrywa do dziś najważniejszą rolę w życiu człowieka. Zbigniew Tyszka podkreślał:

rodzina to strukturalizowany i funkcjonalnie powiązany zbiór jednostek i specyficznych struktur oraz mikroelementów społecznych tworzących mikro grupę i zarazem instytucję społeczną, powiązaną wewnętrzną więzią małżeńską, więzią pokrewieństwa, powinowactwa lub adopcji oraz wypełniającą jednocześnie (symultanicznie) szereg istotnych, ważnych, zintegrowanych ze sobą funkcji wobec jednostek, i społeczeństwa, w oparciu o regulatory występujące w kulturze behawioralnej (Tyszka 1998, s. 77). 
Niewątpliwie w tak zdefiniowanej rodzinie dziadkowie pozostają cennym pokoleniowym ogniwem.

W związku z tym zasadne wydaje się zwrócenie uwagi na proces wychowania i socjalizacji wnuków, w którym starsza generacja w rodzinie pokoleniowej jest fundamentem kształtowania postaw, norm, wartości i symboli kulturowych.

\section{Role (seniorów) dziadków w rodzinie}

W naukach socjologicznych role społeczne definiuje się jako „zbiór norm i wartości związanych z określoną pozycją społeczną, przypisany dla tej pozycji i wymagany od każdego, kto pozycję tę zajmuje" (Sztompka 2012, s. 345). Rodzina i naród to szczególne grupy społecznego funkcjonowania każdego człowieka (rodziców, dzieci, wnuków, dziadków). Tradycyjnymi rolami mężczyzny i kobiety były role ojca i matki. Ojciec zwykle był odpowiedzialny za pracę, kondycję ekonomiczną rodziny. Z uwagi na to, że stanowił łączniki między rodziną a światem zewnętrznym, przysługiwał mu wysoki stopień autorytetu, który warunkował podejmowanie najważniejszych decyzji w rodzinie. Matka natomiast zajmowała się gospodarstwem domowym oraz wychowywaniem dzieci (Goodman 2001, s. 169). Niewątpliwie ważne miejsce $\mathrm{w}$ rodzinie mieli również dziadkowie, których uważano za osoby o bogatym doświadczeniu życiowym odznaczające się mądrością oraz dbałością o przekaz tradycji i pamięci narodowej, a także stojące na straży wartości moralnych i etycznych.

Według L. Troll dziadkowie uczestniczą w różnych ważnych dla rodziny obszarach życia, chociaż zwykle odgrywają w nich role drugoplanowe. Zależą one od: postawy emocjonalnej, więzi międzyrodzinnej, preferencji wartości oraz warunków życiowych. Również kondycja egzystencjalna starszej generacji wpływa na atmosferę $\mathrm{w}$ domu, wspólne bytowanie $\mathrm{z}$ wnukami oraz rodzaj interakcji i wzajemnych odniesień. Niewątpliwie jednak najważniejszą rolą dziadków jest dbanie o holistyczne utrzymanie całego systemu rodzinnego (Szatur-Jaworska, Błędowski, Dzięgielewska 2006, s. 99-100).

W literaturze przedmiotu wskazuje się na wiele postaw i funkcji pełnionych przez dziadków w rodzinie pochodzenia. N. Chmielnicki syntetycznie wskazał pięć stylów życia starszej generacji: formalny charakteryzujący się pewnym dystansem, w którym dziadkowie kontaktują się z wnukami jedynie w zakresie koniecznych kulturowo interakcji; zastępczych rodziców, odgrywających wobec wnuków role rodzicielskie; mądrości rodzinnej, w którym odznaczający się mocnym autorytetem dziadkowie przekazują wnukom tradycje rodzinne; rozrywkowy, w którym dziadkowie stają się bar- 
dzo towarzyscy, zabawowi, a w interakcji z wnukami odwzajemniają wysoki stopień zadowolenia i satysfakcji, oraz życzliwych Mikołajów, którzy dają liczne prezenty, lecz rzadko podejmują kontakty z wnukami (Chmielnicki 1978, s. 29-35).

Problematyka znaczenia dziadków w rodzinie i pełnionych przez nich funkcji była podejmowana też przez T. Kukołowicz oraz I. Rybczyńską. Według T. Kukołowicz szczególną rolę odgrywa babcia. Dlatego też wspomniana badaczka uznaje, że przyjmuje ona role: babci o młodym usposobieniu (jest pełna życia, pasji, oddaje się jeszcze pracy zawodowej, zaś otoczona przyjaciółmi dba o swój wygląd zewnętrzny), babci domatorki (angażuje się w życie najbliższych, chce zajmować się wnukami, z braku zainteresowań swoją aktywność skupia na najbliższej rodzinie), babci niezależnej (niezależna materialnie, mająca swoje hobby, angażująca się w rodzinę w zależności od potrzeb; Kukołowicz 1976). Z kolei I. Rybczyńska podaje szerszy zakres ról współczesnych babć: matkująca, obojętna, wyemancypowana, pretensjonalna, w normie, entuzjastka, dyspozycyjna, wszechmatka, męczennica, dyktatorka (Rybczyńska 1997, s. 136-146).

$\mathrm{Z}$ badań przeprowadzonych wśród studentów przez B. Zięba-Kołodziej wynika, że najważniejszymi rolami dziadków w życiu rodziny są: opieka i wychowanie (sprawowanie opieki, czuwanie nad wychowaniem wnuków, organizowanie wakacji, uczenie odpowiedzialności, cierpliwości i obowiązkowości, miłości i szacunku); nauczanie (pomoc w nauce, uczenie czynności domowych, czytanie bajek, uczenie okazywania uczuć, opiekowania się innymi i rozwijanie empatii); doradzanie (podsuwanie rozwiązań, rozmowy o życiu, wartościach, jak należy postępować); przyjaźń (wspieranie w trudnościach życiowych, pomoc w rozwiązywaniu problemów, bycie powiernikiem tajemnic, gotowość wysłuchania zwierzeń wnuków); sponsorowanie (finansowe i materialne wspomaganie dzieci i wnuków, obdarowywanie prezentami); faktografia (czyli opowiadanie o przeszłości, szczególnie o zdarzeniach historycznych, podtrzymywanie tradycji kulturowych i rodzinnych): gospodarowanie (zajmowanie się domem, sprzątanie, gotowanie), bycie dobrymi duchami (dziadkowie nieżyjący, ale nadal przemawiający do wnuków ustami rodziców; Zięba-Kołodziej 2012, s. 143).

Szczególną funkcję $\mathrm{w}$ systemie rodziny pełnią dziadkowie wobec wnuków, których obydwoje rodzice lub jedno z nich uczestniczy w procesie wewnętrznej lub zewnętrznej migracji zarobkowej. Przyjmują wówczas rolę babci matkującej, charakteryzującej się kompilacją roli babci i matki, zwykle z przewagą zachowań macierzyńskich, a w przypadku dziadka ojcowskich (Wawrzyniak 2011, s. 91).

Niezależnie od przywołanych powyżej stylów życia dziadków, uwarunkowanych charakterem i osobowością człowieka, trzeba dodać, że obecność ich 
wiąże się z miłością, wspólnym bytowaniem, wzajemną pomocą, są też dobrymi opiekunami oraz kronikarzami dziejów rodziny i narodu.

\section{Wychowawcza rola ludzi starszych - od wychowania do socjalizacji}

Wychowanie to proces, który przyjmuje immamentne kontinuum i pozostaje procesem służącym ,do wspierania wpływu na postępowanie innych jednostek" (Znaniecki 2001, s. 5). Chociaż wychowanie i socjalizacja są pojęciami nieco różniącymi się od siebie, to zmierzają w kierunku dobra człowieka. Socjalizacja pozostaje procesem kształtowania rozwoju osobowości, poznania wartości, określonych norm i wzorów kulturowych powszechnie akceptowanych w danym społeczeństwie. Natomiast wychowanie jest „,procesem wywierania celowego wpływu na osobowość człowieka zgodnie z określonym systemem wartości i norm, który realizuje się w relacji wychowawca-wychowanek (Łukow 2007, s. 39). Te dwa pojęcia spajają pierwszorzędne role rodziców i drugorzędne role dziadków. Istnieje jednak potrzeba zachowania równowagi wychowawczo-socjalizacyjnej, aby dzieci i dorastająca młodzież uczestniczyli w integralnym wychowaniu przez rodziców, zaś dziadkowie byli instytucją wspierającą, a z konieczności zastępującą (rodzina zastępcza).

Analizę wychowawczej roli starszej generacji można podzielić na kilka obszarów: wychowanie w rodzinie, wychowanie kulturowe, wychowanie społeczne, wychowanie religijno-moralne.

Dziadkowie, uczestnicząc w funkcji wychowania, przekazują wnukom uformowany kanon wartości obowiązujący w rodzinnej egzystencji ${ }^{1}$. Cechą tego wychowania, jak każdego systemu, również rodzinnego, jest tendencja do zachowania równowagi. Prawidłowość ta określana jako homeostaza oznacza, że w rodzinie istnieją siły dążące do zachowania wewnętrznej równowagi aksjologicznej, której edukacyjnymi aktorami są rodzice i osoby starsze. Aksjologiczny świat rodzinnego systemu często koreluje $\mathrm{z}$ wartościami premiowanymi przez rodziców i dziadków. Z literatury naukowej wynika, że dziadkowie uczą wnuków: prawdomówności, miłości, szacunku, odpowie-

\footnotetext{
${ }^{1}$ Systemowe podejście do rodziny pozwala interpretować ją integralnie w kontekście relacji z innymi członkami rodziny, również z dziadkami w kontekście rodziny biologicznego pochodzenia. Rodzina w interpretacji systemowej jest „zorganizowaną całością, która, chociaż złożona z części, nie jest prostą ich sumą; podsystemami rodzinnymi są relacje małżeńskie małżonków, relacje rodziców i dzieci oraz relacje pomiędzy dziećmi; pomiędzy rodzinnymi podsystemami ma miejsce interakcja - podsystemy na siebie wzajemnie oddziałują; zmiana w którymkolwiek z nich, jeśli okaże się trwała i wystarczająco znacząca, pociąga za sobą zmianę w pozostałych podsystemach, tak by spowodować równowagę systemu już w nowej konstelacji” (Majkowski 2010, s. 29). Z racji wspólnego zamieszkania członków rodziny z dziadkami z natury swej należy ich traktować jako całość w systemie rodzinnym.
} 
dzialności, uczciwości, pracowitości, obowiązkowości, odwagi, cierpliwości, uprzejmości (Pienkoś 2015, s. 285). Z tej też przyczyny charakteryzują się wysokim autorytetem wychowawczym, są autorytetem i wzorem do naśladowania dla wnuków i dlatego dorastający młodzi często do nich zwracają się o porady oraz wtedy, gdy muszą rozwiązywać trudne problemy (Pienkoś 2015, s. 285). Zdaniem M. Szyszkowskiej, to właśnie oni, „mając czas i ogromne doświadczenie, mogliby rozwijać wrażliwość wnuków, wpływać na prawidłowe kształtowanie ich osobowości i człowieczeństwa" (Zięba-Kołodziej, s. 142).

Z kolejnych badań wynika, że do najwyżej cenionych wartości wynoszonych z kontaktów z dziadkami należą: poczucie bycia kochanym, wiara, zasady moralne, znajomość dziejów rodziny, silna wola, samodyscyplina, pracowitość, miłość do ojczyzny. Dlatego starsza generacja jest dla dorastających wnuków cenna również jako nauczyciele relacji rodzinnych, gdyż relacje z nimi poszerzają krąg doświadczeń społecznych i psychicznych, ułatwia zakorzenienie w przeszłości rodziny i sprzyja rozwojowi tożsamości indywidualnej. Wnuki, które spędzają z dziadkami odpowiednią ilość czasu, doceniają ich cierpliwość, ciepłą opiekę, wspólną zabawę. Dzięki interakcji uczą się szacunku do starszego pokolenia, czerpią radość z prowadzonych wspólnie rozmów, cenią ich ciekawe opowiadania, chętnie ich słuchają i korzystają $\mathrm{z}$ ich wartościowych odpowiedzi na zadawane pytania. Dziadkowie odgrywający wychowawczą rolę wobec wnucząt odznaczają się nie tylko hojnością, dobrym sercem, empatią, ale też umiejętnością obrony wtedy, gdy dzieje się krzywda (Wawrzyniak 2011, s. 96-97). Według M. Susłowskiej dzięki edukacyjnej roli starszego pokolenia dzieci od pierwszych lat życia uczą się tolerancji i szacunku wobec bliskich osób, poczucia obowiązku oraz odpowiednich postaw, a także dostrzegania różnych potrzeb innych (Susłowska 1998, s. 13 in.).

Wychowawcza rola starszej generacji w zakresie edukacji aksjologicznej ogniskuje się szczególnie w sytuacji częstej nieobecności rodziców pochłoniętych pracą. $\mathrm{Z}$ tej racji w wielu rodzinach dziadkowie kształtują: kanon wartości, rodzinną atmosferę, potrzebę bliskości, kulturę słowa, postawy wobec innych, relacje i interakcje koleżeńskie, behawioryzm i preferencje wartości oraz zaspokajają potrzeby bezpieczeństwa. Pogląd ten weryfikuje sondaż CBOS przeprowadzony w 2008 roku, z którego wynika, że wnuki zawdzięczają dziadkom: poczucie, że jestem kochany(a), wiarę religijną, zasady moralne, znajomość dziejów rodziny, obowiązkowość, pracowitość, samodyscyplinę, silną wolę, miłość do ojczyzny, opiekę i wychowanie, znajomość ważnych wydarzeń historycznych, praktyczne umiejętności kulinarne, opiekę nad członkami rodziny, majsterkowanie, prowadzenie gospodarstwa rolnego, zamiłowanie do nauki, muzyki, malarstwa, literatury, wędrówki, pasje sportowe, umiejętność gry w szachy (CBOS 2008, s. 4). Cała kafeteria wartości 
wyrażona w powyższym tekście dowodzi słuszności obrony tezy o istotnej roli dziadków w zakresie wychowania.

Kolejnym obszarem edukacyjnej roli starszego pokolenia jest wychowanie kulturowe. Kulturowy proces przyjmuje dwa kierunki. Człowiek bowiem tworzy ją, a ona tworzy człowieka. Stąd też istnieje potrzeba wychowania do kultury, której spoiwem są wartości. Zdaniem B. Nawroczyńskiego, „,cała kultura jest nastawiona na świat wartości i w oderwaniu od niego staje się tylko swoją własną powłoką" (Nawroczyński 1947, s. 75). Dlatego „o wartościach nie sposób mówić poza kulturą [...] one stanowią jej jądro; [...] są aksjologicznym charakterem kultury" (Puzynina 1994, s. 18).

W trakcie edukacji kulturowej następuje przekaz: tradycji, zwyczajów i obyczajów. Tradycja określana jest jako ogół wierzeń, poglądów i obyczajów, które przekazywane są pokoleniowo. Potrzeba zachowania tradycji powinna wynikać z natury i wychowania człowieka. W rodzinie nie chodzi o przekazywanie całości narodowego dziedzictwa, ale o przekaz międzypokoleniowy, czyli proces transmisji elementów kultury, które są istotne dla pamięci członków danej zbiorowości (Szacki 2004, s. 491).

Dziadkowie odpowiedzialni za wychowanie wnuków szczególnie dbają o przekaz wartości, które mają dla nich duże znaczenie i pozwalają kształtować postawy młodszej generacji. Seniorzy główny nacisk kładą zwłaszcza na celebrowanie świąt Bożego Narodzenia, Wielkanocy oraz pamięci swoich przodków, uroczystości rodzinnych i narodowych. Według T. Kukołowicz dziadkowie kształtują u wnuków ich tożsamość rodzinną, regionalną i narodową. Przekazując historię swego życia, podtrzymują kulturę wyrażającą się w ich prawdach życiowych, przyczyniają się do zachowania obyczajów oraz są ośrodkiem rodzinnej informacji, moralnego i materialnego oparcia (Kukołowicz 2006, s. 99). W takiej też interpretacji określają historyczną tożsamość rodziny, kształtują postawy, budzą zainteresowania, stoją na straży transmisji kulturowej, stanowią niejako pomost między tym, co było w przeszłości, a tym, co tworzy teraźniejszość (Szatur-Jaworska, Błędowski, Dzięgielewska 2006, s. 103-104). W tym kontekście J. Wawrzyniak stwierdza, że „,przekazując odpowiednie tradycje, wzorce do naśladowania, są w stanie zapewnić wnukom odpowiedni start $\mathrm{w}$ dorosłe życie. Ważnym aspektem $\mathrm{w}$ tym procesie są bliskie i pozytywne ich kontakty, które umożliwiają zrozumienie psychiki, potrzeb i postaw ludzi starszych" (Wawrzyniak, s. 102).

Przekazywanie nowemu pokoleniu dziedzictwa kulturowego poprzez wprowadzenie go w normy życia zbiorowego, w świat elementarnych wartości kultury ludzkiej rozpoczyna się od najwcześniejszego etapu rozwoju życia dzieci i jest centrum ich integralnego rozwoju: biologicznego, psychicznego, emocjonalnego, społeczno-kulturowego i religijnego. Dzięki uczestnictwu starszej generacji $\mathrm{w}$ transmisji prawdy kulturowej młode pokolenie zinterna- 
lizuje wartości społeczne, tradycje, obyczaje przyjmowane w rodzinie, społeczeństwie, narodzie. Ponadto pielęgnowanie kulturowego środowiska życia dzieci sprawia, że jako ludzie dorośli chętniej będą dokonywały podobnych do starszej generacji wyborów w sferach duchowej i materialnej (Chałas, Kowalczyk 2006, s. 31). Trzeba jednak dodać, że przekaz kulturowy ,pomiędzy pokoleniami jest słabszy w tych rodzinach, w których dziadkowie nie mają tak bliskiej styczności z wnukami, jaka istnieje poprzez opiekę nad nimi i udział w ich wychowaniu. Zakres przekazu dziedzictwa kulturowego zależy od intensywności kontaktów międzypokoleniowych" (Dyczewski 2015, s. 240).

Miłość do ojczyzny, narodu, obywatela, jak każda miłość, czyni człowieka lepszym, skłania do poszukiwania: języka, historii, kultury, religii. Świadczy też o tożsamości społecznej i narodowej. Socjalizacja wnuków na tym polu oddziaływania dziadków obok rodziców uświadamia młodemu pokoleniu wartość własnej ojczyzny i szacunek do niej i zobowiązuje do poznawania innych narodów. Ojczyzna bowiem jest

wspólnotą tych ludzi, którzy widzą w niej dobro wspólne, tj. zespół wartości. Są to wartości różnorodne: materialno-ekonomiczne (ziemia, przemysł, system monetarny), artystyczne (muzea, sztuka, architektura), naukowe i literackie (nauki empiryczne i humanistyczne, literatura piękna), moralno-ideowe (sprawiedliwość, solidarność, honor, ład moralny, miłość społeczna), narodowe (poczucie ciągłości historycznej, patriotyzm, wierność imponderabiliom, gotowość obrony suwerenności politycznej i duchowej narodu) (Chałas, Kowalczyk 2006, s. 31).

Starsza generacja bierze także udział w procesie związanym z socjalizacją. Dziadkowie, podobnie jak rodzice, własnym autorytetem, postawą, wzorem przygotowują wnuki do radzenia sobie w społeczeństwie. Przygotowanie to oparte jest na wartościach, takich jak: zaufanie, godność, wolność, szacunek, pracowitość, odpowiedzialność, tolerancja, solidarność, mądrość, altruizm... W efekcie tych wpływów jednostka przysposabia się do odgrywania różnych ról społecznych implikowanych płcią, osobowością, pełnienia funkcji rodzinnych, zawodowych. Podejmuje działania, które są oczekiwane przez otoczenie warunkujące włączenie się dorastającej osoby w życie społeczne (Adamski 1982, s. 57). W związku z tym dziadkowie są dla wnuków nie tylko nieodłączną częścią rodziny, ale nade wszystko żywymi wzorami odgrywania ról społecznych i wychowawcami.

Istotne jest wychowanie młodego pokolenia do patriotyzmu. Najczęściej definiowany jest on w kontekście miłości ojczyzny, przywiązania do niej, warunkuje cały szereg postaw wyrażających w szacunku do ojczyzny, obywatela, a nawet w konieczności wykazania się heroizmem. Jak uczył Jan Paweł II, „patriotyzm jako miłość ojczyzny przyznaje wszystkim innym narodom ta- 
kie samo prawo jak własnemu, a zatem jest drogą do uporządkowanej miłości społecznej" (Jan Paweł II 2005, s. 51-52).

Wiele badań i naukowa literatura potwierdzają doniosłą rolę dziadków w przekazywaniu patriotyzmu. Między innymi J. Tomiło uważa, że

starsi ludzie, jako świadkowie i uczestnicy obrony wartości patriotyzmu, swoją osobistą historią i zaangażowaniem zaświadczają o sensie patriotyzmu. Skuteczność takiego wychowania patriotycznego podnosi emocjonalny stosunek ludzi starszych do ojczyzny jako dobra wspólnego, jej historii, dorobku materialnego i duchowego Polaków. Jest nim także wychowanie obywatelskie, którego efektem powinno być wyposażenie młodych ludzi w podstawową wiedzę polityczną, prawną i historyczną, pozwalającą im łatwiej zrozumieć istotę procesów społecznych zachodzących w państwie, zasady jego funkcjonowania oraz sens praw i obowiązków obywatelskich, stosunku do władzy i państwa oraz odpowiedzialności za państwo, a ponadto przygotowanie do praktycznego działania i funkcjonowania jako obywatela (Tomiło 2006, s. 212-213).

Oni też dbają o kultywowanie świąt narodowych, państwowych i zachęcają do uczestnictwa w corocznych obchodach uroczystości patriotycznych.

Ostatnią sferą, w której seniorzy odgrywają dydaktyczną rolę, jest wychowanie do wartości religijno-moralnych. W społeczeństwie nowoczesnym nacechowanym indywidualizmem, konsumpcyjną cywilizacją, nastawieniem utylitarystycznym i hedonistycznym rola dziadków wydaje się nieoceniona. Należy dostrzec, że kształtują oni humanistyczne postawy, przekazują normy i zasady moralne, dają świadectwo istnienia i prymatu wartości duchowych. $\mathrm{Z}$ badań wynika, że dziadkowie wpajają wnukom zasady moralne, przekazują wiarę, uczą modlitwy. Ten sposób oddziaływania jawi się jako istotna przestrzeń rozwoju człowieka. Religia i moralność od zawsze stanowiły nierozdzielną sferę życia. Według J. Mariańskiego „obie były włączone w całokształt życia społecznego. Co więcej, były najwyższym gwarantem jednolitego, sensownego - odczuwalnego jako prawomocny - porządku społecznego" (Mariański 2002, s. 46). Niestety współcześnie coraz częściej eliminuje się Boga jako źródło postaw moralnych. W tym kontekście wspomniany powyżej socjolog uznaje, że „,W warunkach postępującej modernizacji społecznej i związanej z nią sekularyzacji słabnie akceptacja wartości i norm głoszonych przez Kościół. Motywacja religijna ustępuje miejsca uzasadnieniom alternatywnym, związanym z czynnikami pozareligijnymi. Następuje stopniowy rozdział religijności i moralności oraz osłabienie rygorystycznego charakteru tradycyjnych norm moralnych" (Mariański 2015, s. 12).Wydaje się, że rozdział ten zaznacza się również w moralnym życiu małżonków i rodziców.

Jeśli szukać spójności życia religijno-moralnego w kontekście społecznych uwarunkowań, trzeba odwołać się do starszego pokolenia. Wielce nie- 
poprawne byłoby twierdzenie, że wszyscy ludzie starsi reprezentują taką postawę. Statystycznie jednak seniorzy wykazują wysoki wskaźnik religijności. Dlatego warto przytoczyć pogląd Z. Struzika twierdzącego, że

starsi stanowią duchowe bogactwo rodziny, ponieważ wprowadzają do nowego pokolenia wartości moralne $\mathrm{w}$ formie dojrzałej i wypraktykowanej. Osoby starsze już swoją obecnością wskazują na to, co w życiu jest prawdziwe, sprawiedliwe, piękne, wartościowe. Swoimi przeżyciami duchowymi wskazują na miłość, jako zasadę życia i współpracy z innymi osobami. Przykład miłości małżeńskiej i rodzinnej jest nieustającym dobrem, jest praktyczną szkołą życia, jest dowodem na wierną, nierozerwalną i dozgonną miłość ludzką (Struzik 2013, s. 120).

Należy również podkreślić znaczącą rolę najstarszej generacji w aspekcie wychowania do cierpienia. Niewątpliwie cierpienie często jest cieniem życia człowieka $^{2}$. Kto je przyjmuje, dostrzega, że jest ono nie tylko jego własnym przeznaczeniem, ale dotyczy każdego człowieka. Ta prawda jawi się jako bardzo oczywista i jasna. „Cierpienie czyni człowieka przewidującym, a świat przejrzystym. Tam w głębi objawia mu się prawda, że byt ludzki jest ostatecznie cierpieniem i że istotnym przeznaczeniem człowieka jest cierpieć - być homo patiens" (Frankl 1978, s. 71). W tym kontekście Jan Szczepański zapisał „musimy akceptować cierpienie jako fakt i składnik życia, musimy mu nadać sens, musimy się z nim liczyć jako z faktem życia zbiorowego z jego funkcjonowaniem w życiu społecznym" (Szczepański 1984, s. 18).

Często cierpienie połączone jest $\mathrm{z}$ dojrzewaniem do odejścia i stopniowym wycofywaniem się z życia doczesnego. Umiejętność poddania się woli Bożej w tym wymiarze egzystencji, a także podsumowania życia, zawierzenia i zaufania, modlitwy i wiary w istniejącego Boga jest świadectwem ludzi umierających. Dzięki temu młodzi mogą zrozumieć istotę cierpienia. Jan Szczepański woła do nich o humanistyczną postawę wobec cierpiących i pisze: „chociaż nie wszystkie rodzaje cierpienia można zakomunikować innym, to jednak człowiek cierpiący oczekuje zrozumienia i pomocy od bliźnich, i ta gotowość pomocy cierpiącym jest praktycznym przejawem humanistycznej postawy" (Szczepański 1986, za: Zych 1999, s. 117). Cierpienie bowiem może prowadzic do poznania Boga i siebie. Człowiek zaś wierzy w Boga albo w bożka, ale wierzyć musi (Scheler 1954, s. 77), inaczej życie nie miałoby sensu.

${ }^{2}$ Warto nadmienić, iż „Bóg jest zawsze po stronie cierpiących. Jego wszechmoc objawia się właśnie w tym, że dobrowolnie przyjął cierpienie. Mógł nie przyjąć. Mógł okazać swoją wszechmoc nawet w momencie ukrzyżowania. Przecież Mu ją proponowano. Zstąp z krzyża, a uwierzymy Ci (por. Mk 15,32). Nie przyjął tej propozycji. To, że pozostał do końca na krzyżu, to, że na tym krzyżu mógł powiedzieć do Boga tak jak wszyscy cierpiący. Boże mój czemuś mnie opuścił (Mk. 15,34) właśnie to pozostało w dziejach człowieka jako najsilniejszy argument. Gdyby zabrakło tego konania na krzyżu, prawda, że Bóg jest miłością zawisłaby w jakiejś próżni” (Jan Paweł II 1994, s. 66). 
Z tego też powodu dziadkowie, którzy doświadczyli wielu trudnych sytuacji i cierpienia, doceniają wartość religii, cenią modlitwę, są pokoleniowymi autorytetami i wzorami dla kształtowania życia religijnego i duchowego wnuków. Natomiast opowiadane przez nich historie całych rodzin i poszczególnych jej członków są lekcjami wychowania moralnego, religijnego i obywatelskiego (Tomiło, s. 206).

\section{Mądrość seniorów (dziadków) - dylematy międzygeneracyjnej so- cjalizacji}

Mądrość jest szczytową cechą człowieczeństwa, czymś, co odróżnia człowieka od innych istot żyjących. Znane są różne formy mądrości: życiowa, uczonego, przedsiębiorcy, polityka, rodzica i starca (Szczepański, s. 258). Szczególnie istotna jest jako wartość umożliwiająca kierowanie życiem, jako umiejętność pomagania, empatii, miłości, jako cnota roztropności oraz afirmacji człowieka.

Ponieważ mądrość jest cechą człowieka, dlatego dzielenie pokoleń na młodsze i starsze wydaje się bezzasadne. Obie te kategorie życia społecznego powinny odznaczać się wartościami: miłości, altruizmu, wsparcia, harmonii życia, służebności, międzyludzkiej solidarności. Słusznie stwierdza A. Zych: „młode pokolenie jest nadzieją każdego narodu, a zarazem ważnym elementem składowym całego społeczeństwa, z kolei generacja seniorów, ludzi sędziwych, jest nośnikiem wielu wartości” (Zych 1999, s. 58). Tymczasem w literaturze i obserwacji społecznej coraz częściej ukazuje się konflikt pokoleń, szczególnie na płaszczyźnie wychowawczej. Być może stereotypowe opinie starszych na temat młodych, np. wyrażane w słowach: ,młodzi to pokolenie burz i naporów oraz irracjonalnego buntu", stanowią przyczynę wielu antagonizmów. M. Czerepaniak-Walczak stwierdza, że „mitologizacje i stereotypizacje młodości i młodzieży jako obrazy umysłowe w głowach jednostek, stanowiące okna do ich świata społecznego upraszczają, a niekiedy wręcz zaburzają odczytywanie zachowań i intencji młodych ludzi" (Czerepaniak-Walczak 2010, s. 53). $\mathrm{Z}$ drugiej strony młodzi nie akceptują stereotypowych opinii na swój temat.

Abstrahując od konfliktu pokoleniowego, warto dodać, że niejednokrotnie na edukację młodego pokolenia korzystnie oddziałują mądrzy, doświadczeni życiowo dziadkowie. Szczególnie widać to na poziomie rozwoju relacji interpersonalnych, co potwierdza myśl amerykańskiego socjologa G. Bossarda, który uważał, że

relacje rodzinne obejmują nie tylko to, co rodzice przekazują swoim dzieciom, zaś dzieci wzajemnie sobie, wnuki swoim dziadkom (dziadki wnukom). Te swe- 
go rodzaju „dary” międzypokoleniowe obejmują m.in. wzbogacenie i umocnienie więzi wewnątrzrodzinnych, emocjonalną satysfakcję, która przenika całość życia rodzinnego, możliwość retrospekcji oraz powrotu myślą czy wspomnieniem do pięknych, przeżytych etapów życia, szansę kontrolowania i korygowania rozwoju osobowości młodego człowieka oraz głębsze zrozumienie procesów życiowych (Bossard za: Zych 1999, s. 61 in.).

Mądrość starców może być też rozpatrywana jako edukacyjny styl życia, którym odznacza się pokolenie starszych. Kofiguratywny styl pokoleniowego przekazu kultury nie powinien być jedynym obowiązującym w procesie socjalizacji ${ }^{3}$. Wyróżniona przez M. Mead typologia systemów kultury dowodzi, że typ kultury postfiguratywnej traci na znaczeniu $\mathrm{z}$ racji upadku autorytetów, które w społeczeństwie tradycyjnym odgrywały znaczną rolę w edukacji młodszej generacji. Autorytet traci również starsza generacja osób. Mimo to kulturotwórcze pokolenie dziadków chce, aby świat ich dzieci i wnuków był taki sam, w jakim oni wzrastali. Zależy im bowiem na kształtowaniu tożsamości młodego pokolenia, chcą być dla nich osobami znaczącymi i akceptowanymi, pełnić wobec nich funkcje normatywne, porównawcze oraz audytoryjne. Dzięki nim młode pokolenie otrzyma instrukcję, jak należy żyć i jak nie należy postępować, oraz wszystkie wzory i cechy kultury warunkujące ich późniejsze funkcjonowanie w społeczeństwie. Problem w tym, że młodzi ludzie współcześnie żyją już w kulturze kofiguratywnej, w której młodsze pokolenia uczą się żyć w otaczającym je świecie, często wzorując się na zachowaniach swoich rówieśników. Dziadkowie nie są w stanie dać im modelu postępowania w nowej rzeczywistości (Niezabitowski 2007, s. 20 in.).

Współczesne społeczeństwo charakteryzuje się standaryzowaną strukturą, rozbudowanym systemem instytucji, to zorganizowana forma współistnienia i współdziałania ludzi różnych zawodów, wierzeń, religii, tradycji kulturowych. W związku z tym nastolatkowie obecnie muszą wybierać spośród różnych, często konkurencyjnych systemów wartości, różnych wzorów osobowych; żyją w świecie idoli kultury masowej. Pokolenie osób dorastających $\mathrm{z}$ racji podejmowania pracy styka się z osobami z wielu grup o rozmaitych stylach życia, wartościach. Funkcjonowanie młodych ludzi w różnych szkołach, pracy, a także migracje i zawieranie małżeństw wielokulturowych sprawiają, że - zgodnie z teorią grup pierwotnych Ch. Cooleya - kultura wyuczona w małej grupie nie zawsze jest wzorem akceptowanym. Opuszczając dom rodzinny, młodzi ludzie tworzą swój własny dom w zupełnie w innym miejscu, a nawet w pewnej odległości od miejsca zamieszkania rodziców i dziadków.

\footnotetext{
${ }^{3}$ Rolę starszego pokolenia w tworzeniu i przekazie wzorów kultury w przekazie międzypokoleniowym prezentuje amerykańska antropolog Margaret Mead, która wyróżnia trzy rodzaje wzorów kulturowych: postfiguratywny, kofiguratywny, prefiguratywny.
} 
Tworzą własną rodzinę prokreacyjną. Stąd też dawny autorytet zanika nie tylko z braku relacji fizyczno-emocjonalnych, ale na skutek przystosowania się młodszego pokolenia do stylów życia i wzorów zachowania, które są nieznane dziadkom (Niezabitowski 2007, s. 20 in.).

Zdaniem wspomnianej M. Mead, kofiguratywny system kulturowy również przechodzi w stan zapomnienia, gdyż na poziomie socjalizacji staje się coraz mniej skuteczny. Przyczyn należy upatrywać w nowoczesnej cywilizacji i postępie technologicznym. Ten rodzaj nowego systemu kulturowego nazywa się prefiguratywnym. Socjalizacja dzieci, wnuków, szczególnie wtórna, sprawia, że rodzice, dziadkowie nie wiedzą, jaki styl życia i system wartości zaproponować wychowankom. Sami zresztą też żyją w systemie anomii aksjologicznej. Ponadto, nawet jeśli preferują jakiś system wartości, to i tak nie bardzo wiedzą, w jakim świecie przyjdzie im bronić tych wartości i czy będzie je można obronić, czy współczesne wzory życia są jeszcze do naśladowania w aspekcie aksjologicznym. Towarzyszy im niepewność związana z tym, czy mają się jeszcze kierować sankcją własnego sumienia, czy przyjąć wzorce płynące ze środków masowego przekazu, iść z duchem epoki, czy pozostać na poziomie własnych wyobrażeń, marzeń, aspiracji, wartości. $Z$ kolei proces edukacji młodzieży będzie nieustannym procesem dokształcania. Nie wystarczy już zatrzymać się jedynie na uczeniu reguł, liczb, bo wszystko to można odnaleźć w pamięci komputerów. Obecnie i tak nastolatkowe wychowują się w świecie obrazkowym, symboli, dotyku ekranowego, w którym smartfon odgrywa rolę przyjaciela, a nawet powiernika różnych spraw. $Z$ kolei ich dorosłe życie będzie nieustannym procesem dokształcania się. Już dzisiaj w przedsiębiorstwach pracownicy zobligowani są do ciągłej edukacji technologiczno-informatycznej. Młodzież jest całkowicie inna od starszej generacji. Pokolenie odchodzących uważa, że wszelkie zmiany w społeczeństwie dokonują się na drodze ewolucji. Mentalność dorastających jest raczej rewolucyjna. Dlatego często tracą wiarę w spójny adaptatywnie funkcjonalny system aksjologiczny o preferencyjnej hierarchii wartości (Niezabitowski 2007, s. 64 in.).

Kończąc analizę dotyczącą kulturowego stylu życia, można odwołać się do dysonansu rysującego się między pokoleniem osób ustępujących a pokoleniem pracujących (rodziców). Wystarczy odwołać się do moralności związanej z życiem sakramentalnym jednych i drugich. Generacja dziadków najczęściej żyje w związkach sakramentalnych, pokolenie rodziców często w związkach pozasakramentalnych. Z kolei dorastający młodzi ludzie poszukują wzorców. Zgodnie z nauką pierwszymi wychowawcami są rodzice, dziadkowie odgrywają role drugorzędne. Być może obecny kryzys wartości przyczynia się do degradacji autorytetów w kulturowym stylu życia.

Może warto zaryzykować stwierdzenie, że międzygeneracyjna teoria wychowania konkluduje się we wzajemnym uczeniu i oddziaływaniu. Pokole- 
nie odchodzących socjalizuje pokolenie młodych w aplikacji wartości, historii życia, dziedzictwa kulturowego, pamięci zbiorowej, świadectwa i przykładu człowieczych postaw. Generacja młodych uczy zaś dziadków aktywności, sprawności informatycznej, nowych technologii, uzupełniania wiedzy zgodnie ze standardami codziennej egzystencji. Szczęśliwi zatem ci, którzy mają wnuki, mogą bowiem im przekazać mądrości życiowe. Szczęśliwi również ci, którzy mogą się uczyć i uczyć innych, chociaż relacje jednych i drugich często tworzą swobodną bliskość, emocjonalność na dystans lub zażyłość na odległość.

Ostatnim aspektem szkicowanej analizy pokolenia starszych niech będzie naukowy komentarz A. Zycha, „niezwykle potrzebne są kontakty i spotkania w dialogu dwóch pokoleń - wstępującego i odchodzącego. Wówczas, poprzez szczery i autentyczny dialog generacji, a nie kontrowersję i konfrontację, łatwiej poszukiwać odpowiedzi na pytanie, jak być w zgodzie z samym sobą i drugim człowiekiem, a zarazem z otoczeniem społecznym" (Zych 1999, s. 62).

Współcześnie rodziny wielopokoleniowe cechujące się względnie stałym i trwałym miejscem egzystencji osób starszych, dające im wysoki status rodzinny i społeczny zostały zastąpione rodziną dwupokoleniową, składającą się z rodziców i dzieci. Można zatem przyjąć pogląd, że kiedyś starcy byli mędrcami, władcami, szanowanymi autorytetami rodzin, a „w obecnych rodzinach, abstrahując od warunków mieszkaniowych, nie ma miejsca dla dziadków" (Dieck za: Zych 1999, s. 12).

Florian Znaniecki uważał, że starsza generacja osób nie ma już mocnego wpływu na wychowywanie młodszej. Przyczyn tego zjawiska upatrywał w zmianie grup, w których przebywają dorastający, jak również w nowych napływających z zewnątrz prądach kulturowych. $Z$ tej racji starsze pokolenie chce, aby młodzi wprowadzali w życie tradycyjny model zachowań kulturowych, szczególnie wychowanie sprzyjające pielęgnacji wartości, godności osoby, okazywaniu szacunku innym. Takie poglądy wydają się sprzeczne $\mathrm{z}$ nowoczesnym podejściem perferującym indywidualizm, utylitaryzm i hedonizm. Społeczeństwo bowiem określa nowe formy młodości obowiązujące w różnych klasach społecznych (Miczyńska-Kowalska 2012, s. 22).

Niewątpliwie seniorzy nadal mają ważny wpływ wychowawczy na dorastających wnuków. Często przejmują oni obowiązki pracujących rodziców. Dobre kontakty z dziadkami uczą nastolatków miłości, troski o drugiego człowieka, poznania historii rodziny, tradycji i wiary praktykowanej w domu. Ten rodzaj inkulturacji: spójny i zasadny, daje podwalinę do ich późniejszego, dobrego funkcjonowania. Ciągle jednak istnieją pewne dylematy i pęknięcia sys- 
temu wychowawczego starszej generacji. Stąd potrzeba działań obligujących do wspólnych dialogów i integracji pokoleniowej.

Oni to niegdyś, jako rodzice wskazywali kierunek działania swoim dzieciom, wszczepiając im taką, czy inną hierarchię wartości, pragnienia, cele i sposoby ich osiągania. Dziś, zarówno przebywając w małym kręgu, w rodzinie, jak i zajmując publiczne stanowiska i urzędy czy też zajmując się twórczością, starsi ludzie mają możliwość, a nawet obowiązek nadal wpływać na młodych ludzi, dostrzegać zło, wskazywać je, ostrzegać przed nim. Powinni udzielać dobrych rad, tłumaczyć, pouczać, zachęcać do czynienia dobrego (Przygoda 2015, s. 40).

Z uwagi na to, że wielu z nich żyło kiedyś w społeczności agrarnej, która przekształciła się w społeczeństwo przemysłowe, postindustrialne, są jeszcze ikonami, strażnikami pamięci zbiorowej, więzi rodzinnych, kronikarzami historii, mądrością wiary, moralności i dziedzictwa kulturowego. Jednakże propozycje i rady udzielane młodemu pokoleniu z pewnością nie dla wszystkich stanowią uniwersalną receptę na szczęśliwe życie.

\title{
THE SOCIO-EDUCATIONAL ROLE OF GRANDPARENTS IN THE FAMILY
}

\begin{abstract}
SUMMARY
The article deals with the educational role of seniors (grandparents) in the family. The aim is to show a specific educative and socializing role in the areas of family upbringing, cultural and social education, religious-moral upbringing and analysis of their rationalized intellectual capital as the wisdom of an old man.

The analysis shows that the roles of seniors still have an important educative impact on adolescent grandchildren. Good contacts with grandparents teach teens love and care for each other, learn about family history, traditions and faith at home. They are still the guards of collective memory, family ties, chronicles of history, wisdom of faith, morality and cultural heritage. It is noticed, however, that advice given to the young generation is not for everyone a universal recipe for a happy life.
\end{abstract}

Keywords: senior, grandparents, family, upbringing, socialization, youth (grandchildren)

Słowa kluczowe: senior; dziadkowie; rodzina; wychowanie; socjalizacja; młodzież (wnuki) 


\section{BIBLIOGRAFIA}

Adamski F. (2002), Rodzina. Wymiar spoteczno-kulturowy, Kraków.

Adamski F. (1982), Socjologia matżeństwa i rodziny, Warszawa.

CBOS (2008), Co im zawdzięczamy? Opinie w przeddzień święta babć i dziadków. BS/3/2008. Warszawa, s. 4.

Chałas K., Kowalczyk S. (2006), Wychowanie ku wartościom narodowo-patriotycznym, Lublin.

Chmielnicki N. (1978), Dziadkowie, babcie, wnuki, „Problemy Rodziny” 1, s. 29-35.

Czerepaniak-Walczak M. (2010), Zaskakujace, intrygujace, niezwyczajne obrazy młodzieży Próba zastosowania koncepcji „Czarnych Łabędzi” w pedagogice mtodzieży, „Przegląd Pedagogiczny" 1 , s. 52-64.

Dieck M. (1979), Wohnen und Wohnumfeld älterer Menschen in der Bundesrepublik, Heidelberg.

Dyczewski L. (2015), Międzypokoleniowe relacje $w$ rodzinie i społeczeństwie, Oświata dorostych. Inspiracje $i$ wyzwania, red. E. Woźnicka, Warszawa-Łódź.

Frankl V.E. (1978), Nieuświadomiony Bóg, tłum. B. Chwedeńczuk, Warszawa.

Goodman N. (2001), Wstęp do socjologii, Poznań 2001.

Jan Paweł II (2005), Pamięć i tożsamość. Rozmowy na przełomie tysiącleci, Kraków.

Jan Paweł II (1994), Przekroczyć próg nadziei, Lublin 1994.

Kukołowicz T. (2006), Jakim wartościom poświęca się wspótczesny stary człowiek, w: Starzenie się a satysfakcja z życia, red. S. Steuden, M. Marczuk, Lublin, s. 197-204.

Kukołowicz T. (1976), Kim jest babcia. Zagadnienia filozofii a zdrowie, Warszawa.

Łukow W. (2007), Problemy wychowania w społeczeństwie globalnym, Olsztyn.

Majkowski W. (2010), Rodzina polska w kontekście nowych uwarunkowań, Kraków.

Mariański J. (2002), Religia i moralność w społeczeństwie polskim: wspótzależność czy autonomia?, „Forum Teologiczne” 3, s. 45-63.

Mariański J. (2015), Religia i moralność w świadomości Polaków: zależność czy autonomia?, „Konteksty Społeczne" 1 (5), s. 8-26.

Miczyńska-Kowalska M. (2012), Socjalizacja w społeczeństwie ponowoczesnym, Lublin.

Nawroczyński B. (1947), Życie duchowe. Zarys filozofii kultury, Kraków-Warszawa.

Niezabitowski M. (2007), Ludzie starsi w perspektywie socjologicznej, Katowice.

Pienkoś M. (2015), Dziadkowie w wychowaniu wnuków na podstawie opinii osób młodych i starszych, „Forum Pedagogiczne” 2, s. 281-289.

Przygoda A. (2015), Spoteczne role dziadków w procesie socjalizacji wnuków, Toruń.

Puzynina J. (1994), Wokót wartości, Edukacja aksjologiczna, red. K. Olbrycht, Katowice, s. 18-32.

Rybczyńska I. (1997), Jak być (kochana) babcia, Warszawa.

Scheler M. (1954), Vom Ewigen in Menschen, Bern-München.

Susłowska M. (1998), Psychologia starzenia sie, Warszawa.

Szacki J. (2004), Tradycja, w: Stownik społeczny, red. B. Szlachta, Kraków, s. 1491-1495.

Szatur-Jaworska B., Błędowski P., Dzięgielewska M. (2006), Podstawy gerontologii społecznej, Warszawa.

Szczepański J. (1984), Sprawy ludzkie, Warszawa.

Szczepański J. (1987), Tworzyć lepszy świat, „Tygodnik Kulturalny” 42, s. 3-4.

Sztompka P. (2012), Socjologia. Analiza społeczeństwa, Kraków.

Tomiło J. (2006), Biografie ludzi starszych jako źródto wartości wychowawczych. Starzenie się a satysfakcja z życia, red. S. Steuden, M. Marczuk, Lublin, s. 205-216.

Tyszka Z. (1998), Socjologia rodziny a pedagogika rodziny. Przedmiot badań-możliwości wspótdziałania badawczego, „Roczniki Socjologii Rodziny” 26 (t. X), s. 77-90.

Wawrzyniak J.K. (2011), Opiekuńczo-wychowawcza rola dziadków w rodzinie, „Pedagogika Rodziny" $1(2)$, s. 95-103.

Struzik Z. (2013), Wartości przekazywane i praktykowane przez osoby starsze w rodzinie, „Mazowsze Studia Regionalne” 13, s. 115-126. 
Zięba-Kołodziej B. (2012), Rola dziadków w życiu rodziny, Tarnobrzeg.

Znaniecki F. (2001), Socjologia wychowania, Warszawa.

Zych A. (1999), Człowiek wobec starości. Szkice z gerontologii społecznej, Katowice.

JÓZEF MŁYŃSKI - kapłan diecezji tarnowskiej, dr hab. w dziedzinie nauk społecznych w zakresie nauk socjologicznych (socjolog) i nauk politycznych (politolog). Wykładowca na Wydziale Studiów nad Rodziną Uniwersytetu Kardynała Stefana Wyszyńskiego w Warszawie. Koordynator Studium Poradnictwa Rodzinnego Pomagam Sobie - Pomagam Innym w Polskich Misjach Katolickich Europy Zachodniej. Pracownik Poradni Specjalistycznej ARKA i Telefonu Zaufania w Tarnowie. Obszary badawcze: socjologia rodziny, polityka społeczna (pomoc społeczna, praca socjalna, samorząd lokalny), socjologia migracji, poradnictwo rodzinne oraz gerontologia. Autor ponad 100 artykułów w językach polskim, niemieckim i angielskim oraz wielu książek. Najważniejsze publikacje książkowe to: $W$ kręgu aksjologii abiturientów Tarnowa, Tarnów 2008; Człowiek wobec pomocy... Zarys pracy socjalnej, Tarnów 2009; Rodzina wobec dylematów migracji zarobkowej, Tarnów 2012; Polityka społeczna wobec rodziny w Polsce w latach 1990-2015, Kraków 2016. 